\title{
RESPONSE TO SELECTION FOR BODY WEIGHT IN THE THIRD GENERATION OF MASS SELECTION OF THE AFRICAN CATFISH (Clarias gariepinus) AT RESEARCH INSTITUTE FOR FISH BREEDING SUKAMANDI
}

\author{
Bambang Iswanto\#, Imron, Huria Marnis, and Rommy Suprapto \\ Research Institute for Fish Breeding
}

\begin{abstract}
Genetic improvement of the African catfish (Clarias gariepinus) in Indonesia for increasing growth performance has been conducted by Research Institute for Fish Breeding at Sukamandi through mass selection. Collection and characterizations of the founder populations, building the synthetic base population, first generation and second generation through mass selection were conducted during 2010-2013. Later, in 2014 it was followed by building the third generation. The present study aimed to find out the genetic gain in the third generation in term of response to selection for body weight. Fifty pairs of the selected (fast growing) individuals from the second generation were mated to produce the third generation. As a comparison, five pairs of average-sized individuals were mated to produce the control population, as a second generation representative. Larval rearing, nursery and grow-out phases were respectively held for 25 days in the aquaria, 30 days in the concrete tanks and 60 days in the concrete ponds. At the end of each phase, individual samplings of body weight were undertaken. The results showed that mean body weight of the third generation was higher than that of control population at the end of larval rearing phase $(0.21 \pm 0.26$ $\mathrm{g}$ versus $0.20 \pm 0.15 \mathrm{~g})$, nursery phase $(6.12 \pm 2.93 \mathrm{~g}$ versus $5.80 \pm 3.50 \mathrm{~g})$ and grow-out phase (198.67 \pm $82.82 \mathrm{~g}$ versus $165.22 \pm 71.09 \mathrm{~g}$ ). Those results revealed that response to selection for body weight of the third generation was positive, i.e. about $20.24 \%(33.45 \mathrm{~g})$.
\end{abstract}

\section{KEYWORDS: African catfish (Clarias gariepinus); body weight; mass selection; response to selection;} third generation

\section{INTRODUCTION}

Introduced African catfish (Clarias gariepinus Burchell 1822) recently becomes a great economically important species in Indonesian aquaculture. It has been cultured vastly throughout Indonesia, mainly in Java, Sumatra, and Kalimantan. African catfish has been several times introduced into Indonesia for aquaculture, either directly from Africa or via other countries. All of those introduced strains exhibited superior growth performance at the beginning of their introductions. Unfortunately, their growth performances were then decreasing. Therefore, genetic improvement program for increasing the growth performance of the African catfish in Indonesia should be carried out in order to increase its productivity in aquaculture industry.

\footnotetext{
\# Correspondence: Research Institute for Fish Breeding. Jl. Raya 2 Sukamandi-Patokbeusi, Subang, West Java, Indonesia 41263. Phone: $+(0260) 520500$ E-mail: bambang.is031@ gmail.com; bambang.is031@ kkp.go.id
}

Genetic improvement program in establishing a new fast growing strain of the African catfish has been conducted by Research Institute for Fish Breeding at Sukamandi since 2010. The genetic improvement program was conducted using mass selection for the growth rate, in term of body weight. Collections and characterizations of the founder populations were conducted in 2010 (Imron et al., 2010; 2011), for which four strains have been collected, namely Paiton, Sangkuriang, Dumbo, and the Egyptian strains. Then, in 2011 it was followed by building the synthetic (composite) base population through diallele crossing of four strains of the founder populations (Iswanto et al., 2012). In 2012, the first generation was established with response to selection of $20.59 \%$ for body weight (Iswanto et al., 2014a). Later, building the second generation was conducted in 2013 resulted in response to selection of $11.80 \%$ for body weight (Iswanto et al., 2014b). Finally, in 2014 it was followed by building the third generation to test the growth performance compared to the second generation. The present study aimed to 
find out the genetic gain resulted in the third generation in term of response to selection (selection response) for body weight.

\section{MATERIALS AND METHOD}

The test of response to selection for body weight in the third generation of African catfish compared to the control population was held in May to September 2014 at Research Institute for Fish Breeding (RIFB) Sukamandi. Fifty pairs of the selected (fast growing, in term of body weight) individuals (breeders) of the second generation were mated to produce the third generation. As a comparison, five pairs of average-sized individuals were mated to produce the control population, as a second generation representative. These mating processes were done artificially using ovaprim (Syndel Laboratories Ltd., Canada) to induce final maturation (ovulation and spermiation). The eggs were obtained through stripping, while the sperm were collected through partial gonadectomy techniques. Approximately $100 \mathrm{~g}$ eggs obtained from each female breeder were fertilized by pooled sperm from all male breeders, then were incubated in separated $1 \mathrm{~m} \times 1 \mathrm{~m}$ tray made from happa placed within indoor concrete tanks with circulated water.

A thousand of two days old larvae obtained from each fertilization process were reared for 25 days within 55 indoor aquaria $(60 \mathrm{~cm} \times 40 \mathrm{~cm} \times 20 \mathrm{~cm})$, i.e. 50 aquaria for the third generation and five aquaria for control population. Brine shrimp (Artemia sp.) nauplii was given as first feed during two days of rearing period, then, in the third day it was partially replaced with chopped silkworms (Tubifex sp.). Within following until fifteenth days of larval rearing period, life silkworms was used as natural feed, which was gradually replaced with commercial fish larval feed contained $40 \%$ crude protein (HI-PRO-VITE PS-P, PT Central Proteinaprima, Mojokerto). This commercial fish larval feed was given until $25^{\text {th }}$ day, partially combined with commercial shrimp larval feed contained $40 \%$ crude protein (BINTANG 581, PT Central Proteinaprima). Those feed were given ad libitum (until apparent satiation) five times daily (at 06:00, 10:00, $14: 00,18: 00$, and 22:00). At the end of rearing period, individual samplings of body weight of $2 \%$ (from initial stock) juveniles from each aquarium were undertaken. Then, juveniles from all aquaria for each third generation and control population were pooled and were graded into $<2 \mathrm{~cm}, 2-3 \mathrm{~cm}, 3-4 \mathrm{~cm}$, and $>$ $4 \mathrm{~cm}$ size class groups.

Juveniles of each size class group were then stocked into five outdoor concrete tanks ( $3 \mathrm{~m} \times 5 \mathrm{~m}$ $x 0.5 \mathrm{~m}$ ) filled with irrigation water for 30 days (one month) of nursery phase with stocking density of 580 fishes $/ \mathrm{m}^{2}$ (equal to 8,700 juveniles/tank). Separation of each size class group juveniles stocked within a same tank (either for the third generation or control populations) was facilitated by net screen. Small crumble sized (BINTANG 581) and crude crumble sized (BINTANG 582) commercial shrimp larval feed with $40 \%$ crude protein content were respectively given for small ( $<2 \mathrm{~cm}$ and $2-3 \mathrm{~cm}$ size class groups) and larger (3-4 cm and $>4 \mathrm{~cm}$ size class groups) juveniles. These feeds were given ad libitum four times daily (at 08:00, 12:00, 16:00, and 21:00) during first ten days or nursery period. Those feed were then gradually replaced with commercial small sized (0.5$1.2 \mathrm{~mm}$ of diameter) floating fish feed contained $40 \%$ crude protein (PRIMAFEED PF 800 and PF 1000, PT Matahari Sakti, Surabaya) given ad libitum thrice daily (at 08:00, 12:00 and 16:00) during 10 $10^{\text {th }}-30^{\text {th }}$ days of rearing period. At $15^{\text {th }}$ day, all of juveniles from each the third generation and control populations were pooled and regrouped via grading into $<3 \mathrm{~cm}, 3-4$ $\mathrm{cm}, 4-5 \mathrm{~cm}, 5-6 \mathrm{~cm}$, and $>6 \mathrm{~cm}$ size class groups. These groups were then restocked into their concrete tanks (separation of each size class group juveniles stocked within a same tank was facilitated by net screen). At the end of nursery phase, individual body weight samplings of $2 \%$ population (from initial stock of each the third generation and control populations) were undertaken. Then, the juveniles from all tanks of each the third generation and control populations were pooled and graded into $<3 \mathrm{~cm}, 3-$ $5 \mathrm{~cm}, 5-7 \mathrm{~cm}, 7-9 \mathrm{~cm}, 9-11 \mathrm{~cm}$, and $>11 \mathrm{~cm}$ size class groups.

Juveniles of each size class group were then stocked into nine outdoor concrete ponds ( $2 \mathrm{~m} \times 10$ $\mathrm{m} \times 0.8 \mathrm{~m}$ ) filled with irrigation water for grow-out phase of 60 days (two months), using stocking density of 200 fishes $/ \mathrm{m}^{2}$ (equal to 4,000 juveniles/pond). Separation of each size class group juveniles stocked within a same pond (either for the third generation or control populations) was facilitated by net screen. Small sized floating fish feed of $30 \%$ crude protein content with $\pm 2 \mathrm{~mm}$ (HI-PRO-VITE 781-1, PT Centralpangan Pertiwi, Karawang) and $\pm 3 \mathrm{~mm}$ (HIPRO-VITE 781-2) of diameter were respectively given for small $(<3 \mathrm{~cm}, 3-5 \mathrm{~cm}$ and $5-7 \mathrm{~cm}$ size class groups) and larger $(7-9 \mathrm{~cm}, 9-11 \mathrm{~cm}$, and $>9 \mathrm{~cm}$ size class groups) juveniles. Those feeds were given ad libitum thrice daily (at 08:00, 12:00, and 16:00) during first ten days of grow-out period. Then, within subsequent ten days of grow-out period, the small size class groups of juveniles were fed with $\pm 3 \mathrm{~mm}$ floating fish feed (HI-PRO-VITE 781-2) and the larger ones with $\pm 4 \mathrm{~mm}$ floating fish feed (HI-PRO-VITE 781). Those feeds were given ad libitum twice daily (at 08:00 and 
16:00). Within following days of grow-out period, all of the juveniles were fed with $\pm 4 \mathrm{~mm}$ floating fish feed (HI-PRO-VITE 781), given ad libitum twice daily (at 08:00 and 16:00). During sixty days of grow-out period, individual body weight samplings of $2 \%$ population (from initial stock of each the third generation and control populations) were conducted every twenty days.

At the end of grow-out period, individual body weight samplings of $20 \%$ population (from initial stock) from each the third generation and control populations were undertaken. Thus, realized heritability and response to selection (Gjedrem \& Baranski, 2009) of the third generation could be determined. Response to selection (R) of the third generation was determined as $R=$ (mean body weight of the third generation - mean body weight of control population). While, realized heritability $\left(h^{2}\right)$ was determined as $h^{2}$ $=$ (response to selection of the third generation : selection differential of the second generation), with the selection differential of the (previous) second generation was about 179.35\%(Iswanto et al., 2014b).

During larval rearing, nursery and grow-out phases of the third and control population of the African catfish held at RIFB Sukamandi, water quality parameters, including water temperature, $\mathrm{pH}$, dissolved oxygen, ammonia and nitrite were recorded at the beginning of the each rearing phase followed by subsequent twice a week recordings. Recordings of water temperature, $\mathrm{pH}$ and dissolved oxygen using digital wa- ter quality checker (TOA DKK WQC-22A, DKK TOA Corporation, Japan) and the concentration of ammonia and nitrite using spectrophotometer (Hitachi UV/ Vis Spectrophotometer U-1500, Hitachi Instruments Inc., USA) were carried out twice daily, in the early morning (at 06:00) and the afternoon (at 14:00).

\section{RESULTS AND DISCUSSION}

Growth performances of the third generation and control population of the African catfish (C. gariepinus) based on individual samplings of body weight at the end of 25 days of larval rearing phase, 30 days of nursery phase and every 20 days during 60 days of grow-out phase were presented in Figure 1. Those results showed that the third generation attained table-size for commonly Indonesian consumers (about $100-150 \mathrm{~g}$ ) at 95 days old or 40 days of grow-out period, while the control population attained it at less than two months of grow-out period. Compared to grow-out phase commonly practiced by African catfish farmers in Indonesia, which were commonly carried out for 2-3 months, those growth performances were comparable.

At the end of larval rearing phase, nursery phase and grow-out phase, mean body weight of the third generation was higher than that of control population (Figure 1). Those results suggested that genetic improvement program in term of increasing the growth performance of the African catfish conducted at the RIFB Sukamandi during three generations of

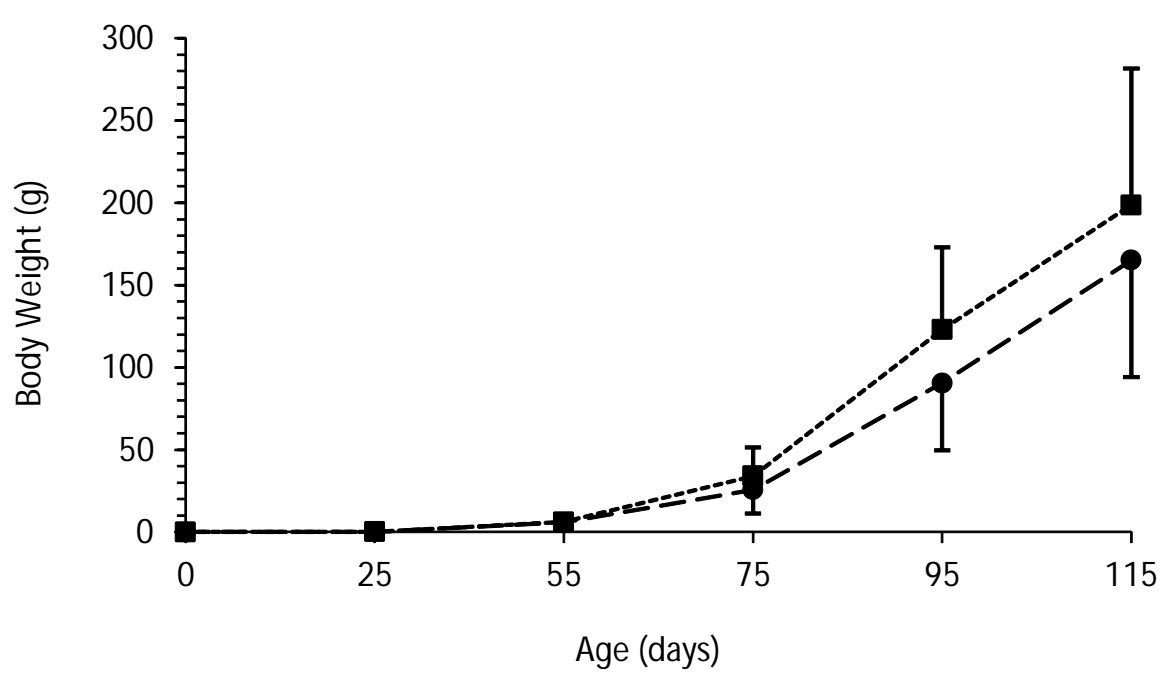

Figure 1. Growth performances based on body weight during 25 days of larval rearing phase, 30 days of nursery phase and 60 days of grow-out phase (based on samplings of $2 \%$ populations) of the third generation $(\bullet)$ and control population $(\bullet)$ of the African catfish (Clarias gariepinus) genetic improvement program held at Research Institute for Fish Breeding, Sukamandi. Vertical lines represent its each standard deviation 
mass selection has gained positive results. Response to selection and final mean body weight of the third generation compared to the control population at the end of larval rearing, nursery, and grow-out phases were presented in Table 1.

Based on those growth performances, final response to selection for body weight in the third generation of mass selection of the African catfish at RIFB Sukamandi was about $20.24 \%$ (33.45 g). This response to selection was similar to that of the first generation, which attained $20.59 \%$ (Iswanto et al., 2014a), but was much higher than that of the second generation, which only attained $11.80 \%$ (Iswanto et al., 2014b). Thus, cumulative response to selection for body weight during three generations of mass selection of the African catfish at RIFB Sukamandi attained $52.63 \%$

The success of genetic improvement programs for increasing the growth performance using mass selection were also reported in several other cultured fish species. Genetic improvement for growth performance of Salmo trutta fario through four generations of enhanced methods of mass selection in France resulted in maximal response to selection for body weight, which attained $130 \%$ (Chevassus et al., 2004). Mass selection for improving the growth performance of Ictalurus punctatus conducted in United States of America resulted in $12 \%$ and $18 \%$ response to selection for body weight in respectively Kansas and Marion strains (Dunham \& Smitherman, 1983). Then, three generations of the mass selection yielded in cumulative response to selection for body weight of $29 \%$ and $21 \%$ in respectively Kansas and Marion strains (Rezk et al., 2003). In Clarias macrocephalus, improving the growth performance through three generations of mass selection conducted in Thailand resulted in $11.8 \%$ response to selection for body weight (Na-Nakorn, 1993). Genetic improvement program for increasing the growth performance of M egalobrama amblycephala conducted in China through five generations of mass selection yielded in $29 \%$ response to selection for body weight (Li \& Cai, 2003). Three generations of mass selection for improving the growth performance of Barbodes gonionotus in Bangladesh resulted in cumulative response to selection of $21.9 \%$ (Hussain et al., 2002).

Genetic improvement program to increase the growth performance using mass selections in the past years, however, were reported to be unsuccessful in Cyprinus carpio (Moav \& Wohlfarth, 1976) and Oreochromis niloticus (Hulata et al., 1986; Huang \& Liao, 1990). Those failed genetic improvement programs by applying the mass selection were, however, caused mainly by low genetic variation in the base populations due to limited number of broodstocks used to produce the offsprings, increasing the inbreeding level and the influence of maternal effects since the use of mass spawnings (Huang \& Liao, 1990; Lutz, 2001; Chevassus et al., 2004; Gjedrem \& Baranski, 2009).

Based on the response to selection for body weight in the third generation of $20.24 \%$ and selection differential for body weight in the establishing the second generation of $179.35 \%$ (Iswanto et al., 2014b), realized heritability for body weight at the end of grow-out phase in the third generation of mass selection of African catfish at RIFB Sukamandi was about 0.12 . This realized heritability was relatively similar to that of the first generation of about 0.10 (Iswanto et al., 2014a), and somewhat higher than that of the second generation of about 0.08 (Iswanto et al., 2014b). Applying the mass selection for improving performance would be effective and produced positive response to selection when heritability of respective trait was high and/or the population size was large, thus high selection differential could be applied (Kapuscinski \& Miller, 2007; Beaumont et al., 2010). Although realized heritability in three generations of mass selection of African catfish at RIFB Sukamandi were low, however, selection differential in establishing the base population (Iswanto et al., 2012), the first (Iswanto et al., 2014a) and second (Iswanto et al., 2014b) generations were high (respectively

Table 1. Response to selection and final mean body weight of the third generation compared to the control population of the African catfish Clarias gariepinus at the end of larval rearing, nursery and grow-out phases

\begin{tabular}{lcccccc}
\hline \multirow{2}{*}{ Phases } & $\begin{array}{c}\text { Periods } \\
\text { (days) }\end{array}$ & \multicolumn{2}{c}{ Final mean body weight (g) } & & \multicolumn{2}{c}{ Response to selection } \\
\cline { 3 - 4 } & & Third generation & Control & & Gram (g) Percentage (\%) \\
\hline Larval rearing & 25 & $0.19 \pm 0.10$ & $0.19 \pm 0.07$ & & - & - \\
Nursery & 30 & $6.12 \pm 2.93$ & $5.80 \pm 3.50$ & & - \\
Grow-out & 60 & $198.67 \pm 82.82$ & $165.22 \pm 71.09$ & 33.45 & 20.24 \\
\hline
\end{tabular}


Table 2. Water quality during 25 days of larval rearing phase, thirty days of nursery phase and sixty days of grow-out phase of the third generation and control population of the African catfish (Clarias gariepinus) genetic improvement program held at Research Institute for Fish Breeding (RIFB), Sukamandi

\begin{tabular}{lccc}
\hline \multirow{2}{*}{ Parameters } & \multicolumn{3}{c}{ Phases } \\
\cline { 2 - 4 } & Larval rearing & Nursery & Grow-out \\
\hline Temperature $\left({ }^{\circ} \mathrm{C}\right)$ & $27.4-28.9$ & $25.5-33.9$ & $28.0-31.5$ \\
$\mathrm{pH}$ & $7.61-8.02$ & $6.10-7.54$ & $5.06-6.98$ \\
Dissolved oxygen $(\mathrm{mg} / \mathrm{L})$ & $5.00-5.80$ & $0.40-11.40$ & $0.44-3.69$ \\
Ammonia $(\mathrm{mg} / \mathrm{L})$ & $0.0320-0.0522$ & $0.1055-0.3753$ & $0.1688-3.8953$ \\
Nitrite $(\mathrm{mg} / \mathrm{L})$ & $0.0178-0.0671$ & $0.0103-0.1728$ & $0.0032-0.1321$ \\
\hline
\end{tabular}

$180.40 \% 179.35 \%$ and $167.50 \%$, therefore still always produced positive response to selection. Mass selection in improving growth performance of 0 . niloticus at Sukabumi produced $2.3 \%$ response to selection for total length, while its realized heritability was 0.12 (Brzeski \& Doyle, 1995). Similar results was also reported for mass selection in improving growth performance of 0 . niloticus in the Philippines, which produced $8 \%$ response to selection for total length, while its realized heritability was 0.16 (Basaiao et al., 2005). The successful genetic improvement program for 0 . niloticus through combined family selection namely GIFT (Genetic Improvement of Farmed Tilapias) project conducted in the Philippines resulted in improved growth performance with cumulative response to selection of $85 \%$ for body weight during five generations, while its heritability were respectively $0.18,0.25,0.18,0.07,0.13$, and 0.09 (Eknath \& Acosta, 1998).

Survival rates of the third generation and control population of African catfish during 25 days of larval rearing phase and 30 days of nursery phase carried out at RIFB Sukamandi were quiet high, respectively $80.14 \pm 10.76 \%$ and $70.58 \pm 11.37 \%$ in the larval rearing phase and respectively $83.16 \%$ and $77.39 \%$ in the nursery phase. Whereas, survival rates during 60 days of grow-out phase were lower, i.e. $68.19 \%$ for the third generation and $66.09 \%$ for the control population.

Those slightly low survival rates in the grow-out phase were caused by relatively high ammonia concentration in the water, which almost reached $4 \mathrm{mg} / \mathrm{L}$. Ammonia concentration over $0.34 \mathrm{mg} / \mathrm{L}$ was not recommended for grow-out phase of the African catfish, even though the threshold concentration was $2.5 \mathrm{mg} / \mathrm{L}$ (Schram et al., 2010). Except for high con- centration of ammonia in the grow-out phase, other water quality parameters during 25 days of larval rearing phase, 30 days of nursery phase and 60 days of grow-out phase in both third generation and control population of the African catfish at RIFB Sukamandi were still in the acceptable ranges required for optimum survival and growth of the African catfish (Table 2), as were recommended by several authors. Recommended optimum water temperature for larval rearing and nursery phases of African catfish ranged $27.5^{\circ} \mathrm{C}-32.5^{\circ} \mathrm{C}$ (Britz \& Hecht, 1987), while for growout phase ranged $27^{\circ} \mathrm{C}-30^{\circ} \mathrm{C}$ (Degani et al., 1988). Well oxygenated water was recommended for larval rearing phase (Britz \& Hecht, 1988), while for nursery and grow-out phases it was not necessary, since African catfish is an air breathing fish that used direct aerial respiration (Teugels, 1986). Median lethal $\mathrm{pH}$ water for African catfish juveniles was reported at 4.3 and 9.2 (Ndubuisi et al., 2015). For nitrite, median lethal concentration for the African catfish was reported at $0.2 \mathrm{mg} / \mathrm{L}$ (Ajani \& Adeyemo, 2012).

\section{CONCLUSION}

Growth performance of the third generation of mass selection of the African catfish (Clarias gariepinus) during 25 days of larval rearing phase, 30 days of nursery phase and 60 days of grow-out phase conducted at RIFB Sukamandi was higher than that of control population, resulted in a positive response to selection for body weight.

\section{ACKNOWLEDGEMENT}

Thanks to all research assistants of the Clarias team of RIFB Sukamandi for their invaluable technical assistances during larval rearing, nursery, and growout phases. This research was funded by Ministry of Marine Affairs and Fisheries. 


\section{REFERENCES}

Ajani, F., \& Adeyemo, O.K. (2012). Nitrite intoxication of Clarias gariepinus at different water temperatures. International Journal of Fisheries and Aquaculture, 4(4), 77-80.

Basaiao, Z.U., Arago, A.L., \& Doyle, R.W. (2005). A farmer-oriented Nile tilapia, Oreochromis niloticus L., breed improvement in the Philippines. Aquaculture Research, 36, 113-119.

Beaumont, A.R., Boudry, P., \& Hoare, K. (2010). Biotechnology and genetics in fisheries and aquaculture. Second Edition. Blackwell Science. Singapore, 202 pp.

Britz, P.J., \& Hecht, T. (1987). Temperature preferences and optimum temperature for growth of African sharptooth catfish (Clarias gariepinus) larvae and post-larvae. Aquaculture, 63, 205-214.

Britz, P.J., \& Hecht, T. (1988). Artificial propagation and fry production. In Hecht, T., Uys, W., \& Britz, P.J. (Eds.). The culture of sharptooth catfish, Clarias gariepinus in Southern Africa. South African National Scientific Programmes Report No. 153 (p. 36-46). Pretoria, Republic of South Africa.

Brzeski, V.J., \& Doyle, R.W. (1995). A test of an onfarm selection procedure for tilapia growth in Indonesia. Aquaculture, 137, 219-230.

Chevassus, B., Quillet, E., Krieg, F., Hollebecq, M.G., Mambrini, M., Faure, A., Labbe, L., Hiseux, J.P., \& Vandeputte, M. (2004). Enhanced individual selection for selecting fast growing fish: the "PROSPER" method, with application in brown trout (Salmo trutta fario). Genetics of Selection and Evolution, 36, 643-661.

Degani, G., Ben-Zvi, Y., \& Levanon, D. (1988). The effect of different dietary protein so urces and temperatures on growth and feed utilization of African catfish Clarias gariepinus (Burchell). The Israeli Journal of Aquaculture - Bamidgeh, 40(4), 113-117.

Dunham, R.A., \& Smitherman, R.O. (1983). Response to selection and realized heritability for body weight in three strains of channel catfish, Ictalurus punctatus, grown in earthen ponds. Aquaculture, 33, 89-96.

Eknath, A.E., \& Acosta, B.O. (1998). Genetic Improvement of Farmed Tilapias (GIFT) Project. Final Report ICLARM. Manila, 173 pp.

Gjedrem, T., \& Baranski, M. (2009). Selective breeding in aquaculture: an introduction. Springer. Netherland, 221 pp.

Huang, C.M., \& Liao, I.C. (1990). Response to mass selection for growth rate in Oreochromis niloticus. Aquaculture, 85, 199-205.
Hulata, G., Wohlfarth, G.W., \& Halevy, A. (1986). Mass selection for growth rate in the Nile tilapia (Oreochromis niloticus). Aquaculture, 57, 177-184.

Hussain, M.G., Islam, M.S., Hossain, M.A., Wahid, M.I., Kahinoor, A.H.M., Dey, M.M., \& Mazid, M.A. (2002). Stock improvement of silver barb (Barbodes gonionotus Bleeker) through several generations of genetic selection. Aquaculture, 204, 469-480.

Imron, Tahapari, E., Sari, R.D., \& Hudaidah, S. (2010). Growth and survival of catfish, Clarias gariepinus, having different domestication history in indoor nursery. Proceedings of International Conference of Aquaculture Indonesia, Hang Tuah University, October 2010.

Imron, Sunandar, D., \& Tahapari, E. (2011). Microsatellite genetic variation in cultured populations of African catfish (Clarias gariepinus) in Indonesia. Indonesian Aquaculture Journal, 6(1), 1-10.

Iswanto, B., Imron, Suprapto, R., \& Marnis, H. (2012). Establishment of a rapid growth strain of African catfish Clarias gariepinus (Burchell, 1822) by means of individual selection: Building the synthetic base population. In Haryanti, Rachmansyah, Sugama, K., Sudradjat, A., Imron, Sunarto, A., Sumiarsa, G.S., Azwar, Z.I., \& Kristanto, A.H. (Eds.). Prosiding Forum Inovasi Teknologi Akuakultur 2012. p. 11971210 (in Indonesian).

Iswanto, B., Imron, Suprapto, R., \& Marnis, H. (2014a). Establishment of a rapid growth strain of African catfish Clarias gariepinus (Burchell, 1822) by means of individual selection: Production the first generation population. J. Ris. Akuakultur, 9(3), 343352. (in Indonesian with English abstract).

Iswanto, B., Imron, Suprapto, R., Marnis, H., \& Ridzwan, N.S. (2014b). Establishment of a rapid growth strain of African catfish Clarias gariepinus (Burchell, 1822) by means of individual selection: Building the second generation. In Sugama, K., Kusnendar, E., Rachmansyah, Giri, I N.A., Yuhana, M., Kristanto, A.H., Imron, Radiarta, I N., \& Dewi, R.R.S.P.S. (Eds.). Prosiding Forum Inovasi Teknologi Akuakultur 2014. p. 837-847 (in Indonesian).

Kapuscinski, A.R., \& Miller, L.M. (2007). Genetics guidelines for fisheries management. University of Minnesota Sea Grant Program. Minnesota, 116 pp.

Li, S.F., \& Cai, W.Q. (2003). Genetic improvement of the herbivorous blunt snout bream (M egalobrama amblycephala). Naga, WorldFish Center Quarterly, 26(1), 20-23.

Lutz, C.G. (2001). Practical genetics for aquaculture. Fishing News Book. London, 252 pp. 
Moav, R., \& Wohlfarth, G. (1976). Two-way selection for growth rate in the common carp (Cyprinus carpio L.). Genetics, 82, 83-101.

Na-Nakorn, U. (1993). Review of aquaculture genetic researches in Thailand. Biotropia, 6, 45-54.

Ndubuisi, U.C., Chimezie, A.J., Chinedu, U.C., Chikwem, I.C., \& Alexander, U. (2015). Effect of $\mathrm{pH}$ on the growth performance and survival rate of Clarias gariepinus fry. International Journal of Research in Biosciences, 4(3), 14-20.

Rezk, M.A., Smitherman, R.O., Williams, J.C., Nichols, A., Kucuktas, H., \& Dunham, R.A. (2003). Response to three generations of selection for increased body weight in channel catfish, Ictalurus punctatus, grown in earthen ponds. Aquaculture, 228, 69-79.

Schram, E., Roques, J.A.C., Abbink, W., Spanings, T., de Vries, P., Bierman, S., van de Vis, H., \& Flik, G. (2010). The impact of elevated water ammonia concentration on physiology, growth and feed intake of African catfish (Clarias gariepinus). Aquaculture, 306, 108-115.

Teugels, G.G. (1986). A systematic revision of the African species of the genus Clarias (Pisces: Clariidae). Annales Musee Royal de l'Afrique Centrale, 247, 1-199. 